Institute of $\mathbf{F}_{\text {ood and }} \mathbf{A}_{\text {gricultural }} \mathbf{S}_{\text {ciences }}$

\title{
Florida Solid and Hazardous Waste Regulation Handbook: Miscellaneous Waste Disposal ${ }^{1}$
}

Michael T. Olexa, Aaron Leviten, and Kelly Samek ${ }^{2}$

\section{What Methods for Disposing of Used Oil Are Prohited?}

Under Florida Statute 403.751, State law prohibits:

- disposing used oil into sewers, drainage systems, septic tanks.

- disposing used oil into any surface water or groundwater, including marine waters.

- disposing used oil in a landfill.

- mixing used oil with solid waste that is intended for disposal in a landfill.

- mixing used oil with hazardous waste so that the oil is unsuitable for recycling.

- common historical practices, such as oiling roads, dust control, weed abatement or other similar activities that would release used oil into the environment.

\section{What Methods for Disposing of Used Oil Are Permitted?}

The best way to dispose of used oil is to present it for recycling. Certain service stations, auto parts stores, and other automotive businesses collect used oil for recycling. Some local governments maintain collection centers; others offer curbside collection.

\section{How May I Dispose of Used Oil Filters?}

Used oil filters must be disposed of properly. The Environmental Protection Agency (EPA) has recently altered its regulations regarding used oil filters. The Florida Department of Environmental Protection (DEP) has taken responsibility for administering these EPA rules. Under the new rules oil filters may not be disposed of in trash as solid waste (except by private homeowners). Private homeowners are still allowed to dispose of used oil filters as solid waste. In all other cases the filters are to be completely recycled (drained, crushed and sent for scrap metal recycling), or tested for toxic characteristics for determination as hazardous waste.

1. This is EDIS document FE458, a publication of the Department of Food and Resource Economics, Florida Cooperative Extension Service, UF/IFAS, University of Florida, Gainesville, FL. Published December 2003. Please visit the EDIS website at http://edis.ifas.ufl.edu.

2. Michael T. Olexa, Professor in the Department of Food and Resource Economics and Director of the Agricultural Law Center, Florida Cooperative Extension Service, UF/IFAS, University of Florida, Gainesville, FL, and Member of the Florida Bar and Chair of the Agricultural Law Committee of the Florida Bar; Aaron Leviten, Attorney in Orlando and guest lecturer on pesticide litigation at the University of Florida; and Kelly Samek, 2003 graduate of the Levin College of Law at the University of Florida.

The Institute of Food and Agricultural Sciences is an equal opportunity/affirmative action employer authorized to provide research, educational information and other services only to individuals and institutions that function without regard to race, color, sex, age, handicap, or national origin. For information on obtaining other extension publications, contact your county Cooperative Extension Service office. Florida Cooperative Extension Service/Institute of Food and Agricultural Sciences/University of Florida/Christine Taylor Waddill, Dean. 
If the filters are found to be hazardous waste under the Toxicity Characteristic Leaching Procedure (TCLP), they must be managed and disposed of as hazardous waste. If the filters are not found to be hazardous they must be drained or crushed and then may be disposed of in a landfill.

\section{How May I Dispose of Waste Tires?}

Waste tires are tires that have been removed from a motor vehicle and are no longer suitable for their original intended purpose. The statute excludes farm tractors and trailers from the definition of motor vehicles, so those tires are exempt. If you have doubts about how to dispose of exempt tires, the existing regulations are good guidelines to follow.

Waste tires may only be disposed of at a permitted solid waste management facility, which includes any facility permitted by DEP for the disposal of waste tires. Whole waste tires may not be disposed of at a landfill. Waste tires that have been cut into sufficiently small parts may be disposed of or used as a cover layer at a permitted landfill.

\section{May I Store My Waste Tires?}

Waste tires may be kept by a business without a permit if, as part of the business, you remove tires from motor vehicles and keep fewer than 1000 waste tires on the business premises. Most farms would probably fall under this definition. Once too many waste tires have accumulated, they must be disposed of properly.

\section{May I Hire Someone to Haul Away My Waste Tires?}

You may not hire a waste tire collector for transportation, disposal, or processing of waste tires unless that collector is registered with DEP. If you hire a waste tire collector to transport more than 25 tires per month you must maintain records. These records must include the date of transportation, number of tires, registration number of the collector and the name of the driver.

\section{How May I Dispose of Lead-Acid Batteries?}

Lead-acid batteries are batteries used in motor vehicles, vessels, or aircraft. These batteries may not be disposed of in a landfill or in a waste-to-energy facility. They may be collected by a metal salvager or exchanged with the purchase of a new battery.

\section{What Are Other Mechanical Wastes?}

Antifreeze is another waste associated with the use of vehicles and other machinery. Used antifreeze may not be disposed of on the ground; in a septic tank, sewer, or storm sewer; nor in a dumpster, even if it is non-hazardous. The antifreeze may be disposed of as a non-hazardous industrial waste if it is indeed not hazardous. Antifreeze must be tested for hazardous properties (specifically for lead, which is also known as $\mathrm{Pb}$ ) to determine how it may be disposed.

Chlorofluorocarbons (CFCs) from automobile air conditioners are also regulated. State law requires that CFCs be recovered through vacuum units, instead of released into the atmosphere.

Most other wastes associated with the use and maintenance of mechanical equipment would be either merely solid waste or hazardous waste and should be disposed of accordingly.

\section{What Are Chemical Wastes?}

Chemical wastes include pesticides and household hazards (e.g., batteries, bleach, paint, and insecticides).

\section{How Does Florida Regulate the Disposal of Pesticides?}

Pesticides are discussed in some detail in the federal section on FIFRA (FE446). Many of the federal requirements are also required by the state. For example, all pesticides sold, used, or transported in Florida must be registered with the Florida Department of Agriculture and Consumer Services (DACS), in addition to EPA. DACS is also responsible for testing and training permit applicants 
and issuing licenses for pesticide applicators, as delegated by EPA under FIFRA. State regulation of pesticides is covered in Chapter 487, Florida Statutes.

\section{How May I Dispose of Pesticide Wastes?}

Disposal of pesticide wastes is really very simple-FOLLOW THE DIRECTIONS ON THE LABEL. If you follow the label instructions, you will be following the law. Some pesticide containers may be burned, recycled, or buried (see the label instructions) if empty and triple-rinsed.

\section{Hay May I Dispose of Pesticides That Have Been Recalled?}

Pesticides that have been placed under stop-sale, stop-use, removal, or hold orders may not be disposed of in any way without a written release from DEP. Usually the substance must be returned to the manufacturer for treatment and disposal.

\section{What Are Household Hazards?}

Household hazards may include:

- cleaning solutions.

- paint.

- paint thinner.

- turpentine.

- batteries.

- insect sprays.

- gardening chemicals.

- many other common, everyday substances found around the house.

Many of the containers for these substances include label directions for disposal and are regulated under FIFRA or other statutes. These label directions carry the force of law. Improper disposal is a violation.
If you have questions about whether a particular chemical or substance may be considered hazardous, contact your county office of waste management, or DEP.

\section{Acknowledgments}

The authors are indebted to the personnel of both state and federal agencies who gave their time and advice in the preparation of this handbook. The authors are also indebted to the following University of Florida personnel for a review and critique of the first draft of this publication: Dr. Thomas Dean, Pesticide Education Specialist, and Dr. Norman Nesheim, Pesticide Information Coordinator. Special recognition is also due to Mr. Richard Budell of the Office of Agricultural Water Policy of the Florida Department of Agriculture and Consumer Services for providing funds for the development of this handbook.

This handbook is designed to provide an accurate, current, and authoritative summary of the principal Florida laws that directly or indirectly relate to agriculture. It should provide a basic overview of the many rights and responsibilities farmers and farmland owners have under Florida laws. The reader is provided information about these rights and responsibilities and the appropriate contacts for more detailed information. However, the reader should be aware that because the laws, administrative rulings, and court decisions on which this publication is based are subject to constant revision, portions of this publication could become outdated at any time. Many details of cited laws are also left out due to space limitations.

This handbook is distributed with the understanding that the authors are not engaged in rendering legal or other professional advice and the information contained herein should not be regarded or relied upon as a substitute for professional advice. It is not all-inclusive in providing information to achieve compliance with laws and regulations governing the practice of agriculture. For these reasons, the use of these materials by any person constitutes an agreement to hold harmless the authors, UF/IFAS, the Agricultural Law Center, and the University of Florida for any liability claims, 
damages, or expenses that may be incurred by any person as a result of reference to or reliance upon the information contained in this publication. 